\title{
Hybrid
}

Revue des arts et médiations humaines

$7 \mid 2021$

\section{Le réseau créatif des langu.ages}

\section{Of Instagrammatology}

\section{Charlie Gere}

\section{(2) OpenEdition \\ Journals}

Electronic version

URL: https://journals.openedition.org/hybrid/708

DOI: $10.4000 /$ hybrid. 708

ISSN: 2276-3538

Translation(s):

De l'Instagrammatologie - URL : https://journals.openedition.org/hybrid/696 [fr]

\section{Publisher}

Presses universitaires de Vincennes

\section{Electronic reference}

Charlie Gere, "Of Instagrammatology", Hybrid [Online], 7 | 2021, Online since 08 April 2021, connection on 13 April 2022. URL: http://journals.openedition.org/hybrid/708 ; DOI: https://doi.org/10.4000/ hybrid.708

This text was automatically generated on 13 April 2022.

Revue Hybrid 


\section{Of Instagrammatology}

\section{Charlie Gere}

1 When Erika Fülöp asked me to write the conference presentation on which this paper is based I was just about to go to India with my wife for a month. As anyone who has been there will confirm India is an overwhelming experience, and my thinking about what to say in this paper was inevitably coloured by that experience. Two aspects of the trip seem particularly relevant. One is that it was my second visit to India, but the first had been over thirty years ago. When I went in 1987, I was as a callow and rather immature twenty five year old. I returned as someone probably not much more mature but nevertheless approaching sixty.

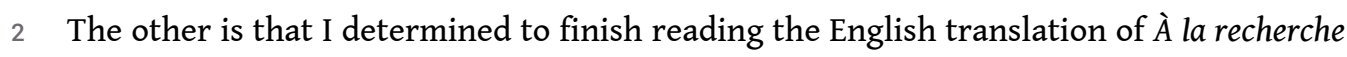
$d u$ Temps perdu by Marcel Proust while in India. This would be the culmination of an attempt to do so that has taken nearly forty years, since my grandmother gave me the three volume Kilmartin translation published by Penguin sometime in the early 1980 s. It seemed particularly important to do so there, because it was there that I had finished the first volume back in 1987, thus ending a process of several years of intermittent reading, and subsequently read the whole of the second volume in a couple of weeks of leisurely train journeys, and days in remote hotels.

3 After returning from India after that first visit, I never seemed able to find the time to read the final volume, so I was determined to do so this time. I also hoped that I might experience Proustian epiphanies in places I had loved the first time, such as Varanasi, but it also seemed strangely apposite to read that volume, which contains Time Regained, Proust's ruminations on the passing of time and of age, in the context of my own experience of time passing between one visit and the next. It is in this volume that Proust describes the aging guests at a reception at the Guermantes as

puppets bathed in the immaterial colours of the years, puppets which had exteriorised Time, Time which by habit is made invisible and to become visible seeks bodies, which wherever it finds it seizes, to display its magic lantern upon them. ${ }^{1}$

4 But it was not just me that had been transformed in the interval between the two visits. The world itself has been utterly changed by one thing in particular. Between 1987 and 
2019 the invention of the World Wide Web, and the increasing ubiquity of digital media and technologies such as smartphones has radically altered our culture.

5 The India I went to in 1987 was still, even more than the Britain I left, an analogue paper culture. Everything was done on and through paper. In three months, I made one phone call home, which had to be booked at a post office, but wrote copious letters, and went eagerly to poste restantes for replies. There were no ATMs and money was only attainable by cashing travellers' cheques. Buying a railway ticket was a positively Victorian affair involving ledgers and copious amounts of paper.

6 There is still a vestige of this paper culture in India, in the vast ledgers used in the cheap hotels we stayed in for example, but of course every hotel of any sort has wifi and Indians are as obsessed by their mobile phones as people elsewhere. I lost count of the number of times my wife and I were asked to pose for group selfies. Our phones allowed us to phone home whenever we wanted, rather than just once as on my previous visit. Facetiming my daughter while in Varanasi when she was walking on a beach in Edinburgh was uncanny, and would have been almost unimaginable in 1987, except in science fiction.

7 Apart from writing letters, which I didn't do much before, or indeed after the trip, I participated in the dominant paper culture in a number of ways; I took books, which I swopped or threw away when I finished them, I kept diaries in a way I have not since, I didn't take either a camera or a Walkman. I kept sketchbooks. In the end, I had four sketchbooks and four volumes of diaries, which I still possess. The sketchbooks, which I think hold up well, are mainly full of mountain, river and sea scenes.

8 I still have the sketchbooks. Many of them include clouds, perhaps because I was there during the monsoon season. The clouds suggest the temporality involved in both making and looking at these sketches. The I who is looking at them has some undoubted continuity with the I who did them three decades ago, and yet is also different. There are scenes recorded in the sketches, and in the diaries I also kept in India, of which I have no recollection. They might as well belong to someone else; to the self I was in my mid-20s, not the self I am in my mid-50s.

9 Perhaps this fixation on representing clouds had some obscure connection to my reading of Proust in India. As Eve Kosofsky Sedgwick points out in her essay The Weather in Proust, the novel shows Proust's great fascination with weather. ${ }^{2}$ The image of a fountain in the garden of the Paris home of the Prince de Guermantes shows

a novelistic vision that combines flexibility with an extraordinary economy, in an endlessly mutable but ultimately closed system where what goes around comes around, where linear narrative is propelled through a perpetual recycling of elements, lives, positions, structures, and desires that honors the conservation of matter and energy, that operates according to law. ${ }^{3}$

Above all it evinces Proust's debt to Neoplatonism. According to Sedgwick,

the philosophical and spiritual discourse of Neoplatonism holds that, in Proust's words, "there exists but a single intelligence of which everyone is co-tenant" (2:195), toward the plenitude of which souls ceaselessly rise and merge, and from which they just as naturally fall and individuate. ${ }^{4}$

11 My Indian diaries are an interesting if predictable mix of rather clichéd awe at the beauties of India, semi-adolescent philosophising and yearning, banal descriptions of meals, and complaints about venial rickshaw drivers and shopkeepers. At the end of 
one of diaries I am fascinated to find an attempt by my twenty-five year old self to describe why I like Proust so much.

Proust - the pleasure in reading equal to the beautiful but frustratingly unfathomable rich of life, especially the sweep of the imagination and the subtleties and vagaries of emotion. The sensual awareness of the whole world he inhabits which in itself is very attractive, especially here in India dreaming about misty mornings becoming sunny in fin-de-siecle France, the pleasures of conversation, friendship, the table, drink, love, warm bodies, the imagination, the countryside and the city, the rain and sun, dusk, night, comfort, the sea, the paintings of Elstir. In order to express why I love Proust properly I would have to become as good a writer as he.

To the side of this appraisal I have added a comparison with Tolstoy, whose War and Peace I had also read in India:

Proust does not give one a fantasy world to retreat to unlike even Tolstoy, but suggests the richness and beauty of an absolutely real life in its depth and normalcy. How attractive are the bourgeois scenes that Marcel awakes in. We share in his sensual and imaginative apprehension of scenery and weather, people and places.

What is curious and what distances the self who went to India in 1987 and the one who went in 2019, is that, this time, I found Proust boring. Admittedly the point at which I restarted my reading, The Captive [La Prisonnière], is notoriously troublesome, not least because of its sexual and gender politics. In the end I could barely bear to read another word on Albertine, the least convincing woman in great literature. Of course there were some great parts, the uneven paving stone, the aging members of society at the Guermantes party and so on, but in the end I was wishing that an editor had taken the whole thing robustly in hand.

However the fault was not entirely Proust's. It was mine as well of course, in the sense that I had changed, greatly, in the intervening years between readings. In fact the me who went to India the first time seemed, seems an entirely different individual to the one who went the second time.

Galen Strawson takes great issue with what he describes as a "fallacy of our age," the idea that we all conceive of our lives as narratives, and that this is a good thing, or even the only way to live. ${ }^{5}$ Strawson refutes this and suggests that it is perfectly possible and maybe more desirable to be what he calls an "episodic," as opposed to a "diachronic." He names as representatives of the former Petrarch, Derek Parfit, Michel de Montaigne, the Earl of Shaftesbury, Laurence Sterne, Coleridge, Stendhal, Hazlitt, Ford Madox Ford, Virginia Woolf, Jorge-Luis Borges, Fernando Pessoa, Iris Murdoch, Freddie Ayer, Bob Dylan, Emily Dickinson, and Proust, "for all his remembrance (which may be inspired by his Episodicity)." Among the latter he includes Plato, St. Augustine, Heidegger, Wordsworth, Dostoyevsky, Joseph Conrad, Graham Greene, Evelyn Waugh, Patrick O'Brian, and all the champions of Narrativity in the current ethico-psychological debate. $^{7}$

\section{According to Strawson the}

basic form of Diachronic self-experience [D] is that one naturally figures oneself, considered as a self, as something that was there in the (further) past and will be there in the (further) future - something that has relatively long-term diachronic continuity, something that persists over a long stretch of time, perhaps for life. ${ }^{8}$

By contrast as an Episodic 
one does not figure oneself, considered as a self, as something that was there in the (further) past and will be there in the (further) future, although one is perfectly well aware that one has long-term continuity considered as a whole human being. Episodics are likely to have no particular tendency to see their life in Narrative terms. ${ }^{9}$ Heidegger believed to be peasant boots with Andy Warhol's Diamond Dust Shoes. The former offers us readings that are "hermeneutical, in the sense in which the work in its inert, objectal form is taken as a clue or a symptom for some vaster reality which replaces it as its ultimate truth." 12 The latter, by contrast, is "first and most evident is the emergence of a new kind of flatness or depthlessness, a new kind of superficiality in the most literal sense."13 Jameson points to "the role of photography and the photographic negative in contemporary art of this kind." ${ }^{14}$ Unlike the Van Gogh in which "a stricken world is by some Nietzschean fiat and act of the will transformed into the stridency of Utopian color," in the Warhol "it is as though the external and colored surface of things - debased and contaminated in advance by their assimilation to glossy advertising images - has been stripped away to reveal the deathly black-and-white 
substratum of the photographic negative which subtends them." ${ }^{15}$ In her classic work on photography Susan Sontag points out that

Whenever Proust mentions photographs, he does so disparagingly: as a synonym for a shallow, too exclusively visual, merely voluntary relation to the past, whose yield is insignificant compared with the deep discoveries to be made by responding to cues given by all the senses - the technique he called "involuntary memory." One can't imagine the Overture to Swann's Way ending with the narrator's coming across a snapshot of the parish church at Combray and the savoring of that visual crumb, instead of the taste of the humble madeleine dipped in tea, making an entire part of his past spring into view. ${ }^{16}$

For Jean-Paul Sartre, similarly, Proust was the epitome of the mistaken search for an interior consciousness which consumes and dissolves the world. For Sartre, Husserl's phenomenology and Heidegger's "being-in-the-world" show us that "consciousness has no 'inside'." As Sartre puts it,

We can leave Proust behind now. And, with him, the "inner life": in vain would we seek ... like a child kissing her own shoulder, the caresses and fondlings of a private intimacy, since, at last, everything is outside. Everything, including ourselves. It is outside, in the world, among others. It is not in some lonely refuge that we shall discover ourselves, but on the road, in the town, in the crowd, as a thing among things, and a human being among human beings. ${ }^{17}$

Of course, Sartre is being unfair to Proust, using him as a kind of straw man to chastise certain ideas of interior consciousness. And I am being unfair to him as well, but there is arguably nothing more Proustian than no longer loving Proust as I once did. In his short but wonderful book The Living and the Dead, Toby Austin Locke shows Proust to be one of the most radical critics of the illusion of interiority, not least because he changes his mind about what or whom he loves. As Locke puts it, "Throughout Proust's search the self dies and is born." Indeed, "there is a continual proliferation of selves, a literary ecology of selves." ${ }^{18}$ Even in the book itself, "there is a multiplicity of selves that cannot be reduced to each other, and that communicate endlessly - we are never sure where Proust ends and The Search begins, where the author and narrator converge." ${ }^{19}$ Locke picks out the section at the beginning of Time Regained, in which

the narrator of The Search finds that the paths upon which he trod in the past no longer hold the same wonder and amazement, and that the woman with whom he treads them, having once been the centre of his affections, no longer appears to him even as beautiful. The duration through which he has travelled has seen him so transformed that the perspective of apparent former self now appears as alien to him. The vision of his youth, the beauty, wonder and excitement it perceived, has fallen through his hands; no longer do the places resonate as they once did. This death of the self is re-enacted countlessly, but it always brings with it birth. ${ }^{20}$

Thus for Locke, the narrator of The Search is not "one discreet individual simply transforming but remaining continuous and self-same, but a proliferation of individuals entering into tiny births and deaths." ${ }^{21}$ (Given this, it's little wonder that writers such as Pico Iyer and Pankaj Mishra see Proust as, in Iyer's formulation, taken from Henri Cartier Bresson's own self-description, as an "accidental Buddhist.")

Perhaps this makes Proust an appropriate writer for the era of the World Wide Web. In his book Proustian Space; Georges Poulet proposes that the narrator's experience of the magic lantern in his bedroom at Combray prefigures what he describes as the "wavering" of time and space experienced throughout the book by the narrator, in which "[a] place tries to substitute itself for another place; to take its place."22 This is how he characterises the experiences of mémoire involontaire for which the novel is 
famous. For Poulet, "Proustian memory" presents the narrator with spaces which are "vacillating and substitutionable." ${ }^{23}$ Such an experience makes "the mind totter between two distinct epochs; forces it to choose between mutually incompatible places" and to "'oscillate' between years long past and the present time." ${ }^{24}$ This experience, which for the youthful narrator is uncanny, literally unheimlich or unhomely, is for us commonplace. Our private spaces are porous, allowing the intrusion and superimposition of other times and places, through telephones, radio, recorded music, television, video, and the computer. In a crude sense Proust's experience of mémoire involontaire, prefigured in the magic lantern, is a kind of protoweb, albeit linked into the closed circuit of the narrator's memory and imagination.

At least one passage in the Recherche suggests that he was vaguely aware of such future possibilities, when he remarks of Albertine's voice that it was "like what we are promised in the photo-telephone of the future: the visual image was clearly outlined in the sound." ${ }^{25}$ But this does not indicate any unusual degree of prescience. By the time he wrote this photo-telephones had already been a stock item for cartoonists for some time. This apparently private and idiosyncratically Proustian experience was, in fact, an aspect of the cultural context in which he lived. According to Walter Benjamin the ascension of Louis-Philippe in 1830 after the July Revolution marked the entry of the private citizen upon the historical scene. One result of this was that

[f]or the private citizen, for the first time the living-space became distinguished from the place of work. The former constituted itself as the interior. The private citizen ... required of the interior that it should support him in his illusions ... from this sprang the phantasmagorias of the interior. This represented the universe for the private citizen. In it he assembled the distant in space and in time. His drawing room was a box in the world theatre. ${ }^{26}$

The period around 1830 also, far from coincidentally, represents the moment when many modem technologies of communication and representation were first developed, including photography in the late eighteen twenties, telegraphy in the late eighteen thirties, and even, starting in the early eighteen twenties, Babbage's attempts to build what we now recognise as computers. Out of these developments derived almost all consequent information and communication technologies, many of which first emerged in Proust's lifetime, including telephony, radio, film, computing and television.

It is not surprising that Proust, one the most articulate exponents of bourgeois interiority, should reflect the tele-visual concerns of the bourgeoisie. It is possible to go further and suggest that he prefigures not just television, but later developments as well. The Recherche is a marvellous exegesis of the perverse corollary of the privatisation of experience described above, the realisation of the impossibility of a unified subject and the apprehension of the multiple and fractured nature of the self and of experience. In this it prefigures the distributed selfhood paradigmatic of our contemporary technologically mediated culture. Indeed the episodes of mémoire involontaire can be read as a kind of hypertextuality, in which the linear text of the narrator's progress through time is interrupted by non-linear jumps, remote control zappings, to other times and spaces in the world wide web of his memory. George Landow proposes something of the sort in his book Hypertext. The Convergence of Contemporary Critical Theory and Technology. He suggests that Proust "conveys the experience of encountering the disjunctions and jumps of hypertextual narrative." ${ }^{27}$ In this context it is hard to resist quoting from Walter Benjamin's essay on Proust, in 
which he reminds us that the "Latin word textum means 'web'. No one's text is more tightly woven than Marcel Proust's." 28

Proust's narrator weaves this web in order to put off what ultimately cannot be avoided, "closed down," in other words, death. The narrator of the Recherche is like Scheherazade, ever reprieved from execution by the Sultan Shahriyar by her capacity to continue telling tales. As J. Hillis Miller has pointed out in his essay "Fractal Proust," the whole of the Recherche is an enormous detour on the way to death. And yet, of course, the end cannot be put off. Even those means by which arrival at this destination is apparently forestalled, bring it closer. ${ }^{29}$

31 At the same time death can be, apparently, overcome in the experience of involuntary memory. It is in the volume of Proust I read in India that the narrator describes stumbling against some unevenly placed paving stones in the courtyard of the Guermantes mansion, where he is going to a soiree. As he stumbles, "a profound azure intoxicated my eyes, impressions of coolness, of dazzling light, swirled around me," he writes. ${ }^{30} \mathrm{He}$ tries to repeat the stumble in order to recapture the feeling. He realises that

every time that I merely repeated this physical movement, I achieved nothing; but if I succeeded, forgetting the Guermantes party, in recapturing what I had felt when I first placed my feet on the ground in this way, again the dazzling and indistinct vision fluttered near me, as to say: "Seize me as I pass if you can, and try to solve the riddle of happiness I set you." ${ }^{31}$

Eventually he realizes that the sensation has recalled is one he "had once experienced as [he] stood on two uneven slabs in the Baptistry of St. Mark" in Venice. It "restored to [him] complete with all the other sensations linked on that say to that particular sensation all of which had been waiting in their place." ${ }^{32}$ This and other such visions had "given [him] a joy which was like a certainty and which sufficed, without any other proof to make death a matter of indifference to [him]." ${ }^{33}$

But the answer to the riddle set by the uneven cobblestone is that "the true paradises are the paradises we have lost." ${ }^{34}$ For all the joy that this moment gives the narrator, it is set around with sadness at the endless loss of each instant. In his book on the instant, the philosopher Gaston Bachelard alludes to Proust when he remarks that "the shadow of mute suffering stalks us whenever we go in search of lost instants." ${ }^{35}$ For Bachelard time is composed solely of instants, not, as Henri Bergson would have it, of duration. Bachelard took his cue from the work of the historian Gaston Roupnel, whose decisive metaphysical proposition is, according to Bachelard, that

Time has but one reality, the reality of the instant. Otherwise put, time is a reality confined to the instant and suspended between two voids. Although time will no doubt be reborn, it must first die. It cannot transport its being from one instant to another in order to forge a duration. The instant is already solitude ... It is solitude in its barest metaphysical value. Yet an even more poignant solitude confirms the tragic solitude of the instant: through a sort of creative violence, time limited to the instant isolates us not only from others but even from ourselves, since it breaks with our most cherished past. ${ }^{36}$

Bachelard follows this claim with a direct quote from Roupnel.

The instant that has just fled from us is the same vast death that holds dominion over abolished worlds and extinguished firmaments. And the same fearsome unknown holds the approaching instant within the dark shadows of the future, as much as it does the Worlds and the Heavens that have yet no inkling of themselves. 
does sound somewhat Buddhistic. As the Routledge Encyclopaedia of Modern French Thought suggests, Bachelard's idea of time was "without precedent in Western Philosophy, but it is strikingly close to the views put forth by some Buddhist philosophers (particularly of the school of Dignana)." 38 Dignana and his follower Dharmakirti were part of the Apoha school of thought which espoused a form of Nominalism and "momentariness." ${ }^{39}$ Martin Jay invokes what he calls "Magical Nominalism" to describe the particular nature of photography.

Although we know that photographs, even before the age of digitalization, are amalgams of the instant of their being taken and the subsequent work on them in the developing, printing and displaying processes, that instant is never entirely absorbed into those posterior interventions. ${ }^{40}$

Jay finds in the photograph what he calls "the counter-assertion of the world, a world more readymade than the product of human will, a world that somehow stubbornly thwarts all of our best - or is it worst? - efforts to disenchant it." This he calls a "magical nominalism of the camera" which "begins to resemble a realism of particulars" and produces "a realism of proper names that paradoxically comes from the world and not the naming subject, a world that has not entirely lost its capacity to inspire awe, wonder and humility." ${ }_{41}$

Yet it may be possible that each instant both disappears and remains. One of the strangest ideas in Quantum Physics is Hugh Everett's “many-worlds” interpretation, which, put simply, suggests that everything that might happen has, and there are an enormous or perhaps infinite number of parallel universes, each the result of a different outcome at each moment in time. It is something like Jorge Luis Borges' garden of the forking paths, taken to its logical conclusion. Everett himself, convinced, perhaps, of his "quantum immortality" drank and smoked himself to death from a heart attack at the age of fifty-one. Absurd as Everett's idea may sound there are physicists, such as Max Tegmark, who take it seriously. Len Pisman, however, claims that "there are too many forks that can be encountered in a continuous manner, and not only by yourself, but by other people and other creatures and all kinds of quantum particles, even in remote galaxies: and they may all affect you. There are just too many universes!" Pismen suggests that no one could ever count them but they could be "assigned Cantor's number Aleph-Infinity." 42

Here Pisman is referring to the mathematician Georg Cantor's revolutionary development of set theory. Put as simply as I am able, this theory proposes that there are an infinite number of infinite sets, the smallest (!) of which is any countable set, such as the infinite number of natural numbers, integers, 1,2 , 3, etc...., which is what Cantor calls Aleph Null (or Zero, or Nought, or 0). Other infinite sets, such as that of the rational numbers $(1 / 1,1 / 2,1 / 3$, and so on) are also Aleph Null. An infinity remains Aleph Null as long as if it can be put in one to one correspondence with the natural numbers. However, there are larger infinities, such as Aleph One, Aleph Two, and so on. This is because there are sets of numbers that are not countable, inasmuch as any attempt to match each one in such a set with counterpart in a set of countable numbers will always leave out members of former. An example of such a set is that of real numbers, which includes not just natural numbers and rational numbers, but also irrational numbers such as Pi. Cantor shows it is, provably, a bigger infinity than a countable Aleph Null infinity. 
It may take Aleph Infinity to count all the universes generated in Everett's many worlds, but all of human representation can perhaps be realized digitally in the infinity of Aleph Null. This, at least, is the claim of computer scientist Oli Sharpe in his paper "All human discourse is trapped in Aleph Zero." Taking his cue from Jorge Luis Borges' story "The Library of Babel." Sharpe imagines the possibility of encoding and recording every possible digitally recordable act of communication, text, image, sound, video, not only those that have been but could and will be in the future, all which can be contained in the infinity of Aleph Zero. Thus "to faithfully record all human attempts to communicate ever will 'only' require a finite description length! (the 'only' is in quotes because this finite number will obviously be extremely large)." This leads Sharpe to three points:

1. The total number of recordable communication acts that are actually made by all humans ever will be in aleph-zero (where "in aleph-zero" means less than or equal to aleph-zero).

2. The total description length of a set of high-fidelity recordings of all these actual communication acts will also be in aleph-zero.

3. Even the description length of all conceivable high-fidelity recordable content that humans could ever produce is in aleph-zero.

\section{BIBLIOGRAPHY}

Bachelard, Gaston, Intuition of the Instant, Evanston, Illinois, Northwestern University Press, 2013. Benjamin, Walter, Illuminations, New York, Schocken, 1968.

Jameson, Fredric, Postmodernism, or, The Cultural Logic of Late Capitalism, Durham, Duke University Press, 1991.

Jay, Martin, "Magical nominalism: Photography and the re-enchantment of the world," Culture, Theory and Critique, vol. 50, no. 2-3, 2009.

Landow, George P., Hypertext. Convergence of Contemporary Critical Theory and Technology, Baltimore, Johns Hopkins University Press, 1992.

Locke, Toby Austin, The Living and the Dead, London, Repeater Books, 2016. 
Malraux, André, Le Musée Imaginaire. Les voix du silence, Paris, Gallimard, 1965.

Miller, J. Hillis and Manuel Anensi, Black Holes. J. Hillis Miller, or Boustrophedonic Reading, Stanford, Stanford University Press, 1999.

Murray, Christopher John (ed.), Encyclopedia of Modern French Thought, Routledge, London/ New York, Routledge, 2004.

Pisman, Len, The Swings of Science. From Complexity to Simplicity and Back, Cham, Springer, 2018.

Poulet, Georges, Proustian Space, Baltimore/London, Johns Hopkins University Press, 1977.

Proust, Marcel, In Search of Lost Time, vol. 2, Within a Budding Grove, translated by C. K. ScottMoncrieff and Terence Kilmartin, New York, Vintage, 1996.

Proust, Marcel, In Search of Lost Time, vol. 6, Time Regained, translated by Andreas Mayor and Terence Kilmartin, New York, Vintage, 1996.

Sedgwick, Eve Kosofsky, The Weather in Proust, Durham, NC, Duke University Press, 2011.

Sharpe, Oli, "All recordable human discourse is trapped in aleph-zero," presented at the 09/2018, PPIG 2018 - 29th Annual Conference, 2018. [Online] https://www.ppig.org/files/2018-PPIG-29thsharpe.pdf [accessed 13 April 2021].

Sontag Susan, On Photography, Harmondsworth, Penguin, 1979.

Strawson, Galen, Things That Bother Me. Death, Freedom, the Self, etc., New York, New York Review Books, 2018.

Tillemans, Tom, "Dharmakīrti," in Edward N. Zalta (ed.), The Stanford Encyclopedia of Philosophy (Spring 2017 Edition). [Online] https://plato.stanford.edu/archives/spr2017/entries/ dharmakiirti/ [accessed 13 April 2021].

\section{NOTES}

1. Marcel Proust, In Search of Lost Time, vol. 6, Time Regained, translation Andreas Mayor and Terence Kilmartin, New York, Vintage, 1996, p. 290-91.

2. Eve Kosofsky Sedgwick, The Weather in Proust, Durham, NC, Duke University Press, 2011.

3. Eve Kosofsky Sedgwick, The Weather in Proust, Durham, NC, Duke University Press, 2011, p. 3.

4. Eve Kosofsky Sedgwick, The Weather in Proust, Durham, NC, Duke University Press, 2011, p. 2.

5. Galen Strawson, Things That Bother Me. Death, Freedom, the Self, etc., New York, New York Review Books, 2018, p. 45.

6. Galen Strawson, Things That Bother Me. Death, Freedom, the Self, etc., New York, New York Review Books, 2018, p. 47.

7. Galen Strawson, Things That Bother Me. Death, Freedom, the Self, etc., New York, New York Review Books, 2018, p. 50.

8. Galen Strawson, Real Materialism and Other Essays, Oxford, New York, Oxford University Press, 2008, p. 190.

9. Galen Strawson, Real Materialism and Other Essays, Oxford, New York, Oxford University Press, 2008, p. 191.

10. Galen Strawson, Real Materialism and Other Essays, Oxford, New York, Oxford University Press, 2008, p. 194.

11. André Malraux, Le Musée Imaginaire. Les voix du silence, Paris, Gallimard, 1965.

12. Fredric Jameson, Postmodernism, or, The Cultural Logic of Late Capitalism, Durham, Duke University Press, 1991, p. 8. 
13. Fredric Jameson, Postmodernism, or, The Cultural Logic of Late Capitalism, Durham, Duke University Press, 1991, p. 9.

14. Fredric Jameson, Postmodernism, or, The Cultural Logic of Late Capitalism, Durham, Duke University Press, 1991, p. 9.

15. Fredric Jameson, Postmodernism, or, The Cultural Logic of Late Capitalism, Durham, Duke University Press, 1991, p. 9.

16. Susan Sontag, On Photography, Harmondsworth, Penguin, 1979, p. 164.

17. Jean-Paul Sartre, Critical Essays (Situations I), London, Seagull Books, 2010, p. 45-46.

18. Toby Austin Locke, The Living and the Dead, London, Repeater Books, 2016, p. 68.

19. Toby Austin Locke, The Living and the Dead, London, Repeater Books, 2016, p. 68.

20. Toby Austin Locke, The Living and the Dead, London, Repeater Books, 2016, p. 68-69.

21. Toby Austin Locke, The Living and the Dead, London, Repeater Books, 2016, p. 70.

22. Georges Poulet, Proustian Space, Baltimore/London, Johns Hopkins University Press, 1977, p. 10.

23. Georges Poulet, Proustian Space, Baltimore/London, Johns Hopkins University Press, 1977, p. 11.

24. Georges Poulet, Proustian Space, Baltimore/London, Johns Hopkins University Press, 1977, p. 11.

25. Marcel Proust, In Search of Lost Time, vol. 2, Within a Budding Grove, translation C. K. ScottMoncrieff and Terence Kilmartin, New York, Vintage, 1996, p. 589-90.

26. Walter Benjamin, The Arcades Project, Cambridge, MA, Belknap Press, 1999, p. 8-9.

27. George P. Landow, Hypertext. Convergence of Contemporary Critical Theory and Technology, Baltimore, Johns Hopkins University Press, 1992, p. 114.

28. Walter Benjamin, Illuminations, New York, Schocken, 1968, p. 202.

29. J. Hillis Miller and Manuel Anensi, Black Holes. J.Hillis Miller, or Boustrophedonic Reading, Stanford, Stanford University Press, 1999, p. 317.

30. Marcel Proust, In Search of Lost Time, vol. 2, Within a Budding Grove, translation C. K. ScottMoncrieff and Terence Kilmartin, New York, Vintage, 1996, p. 217.

31. Marcel Proust, In Search of Lost Time, vol. 2, Within a Budding Grove, translation C. K. ScottMoncrieff and Terence Kilmartin, New York, Vintage, 1996, p. 217.

32. Marcel Proust, In Search of Lost Time, vol. 2, Within a Budding Grove, translation C. K. ScottMoncrieff and Terence Kilmartin, New York, Vintage, 1996, p. 218.

33. Marcel Proust, In Search of Lost Time, vol. 2, Within a Budding Grove, translation C. K. ScottMoncrieff and Terence Kilmartin, New York, Vintage, 1996, p. 218.

34. Marcel Proust, In Search of Lost Time, vol. 2, Within a Budding Grove, translation C. K. ScottMoncrieff and Terence Kilmartin, New York, Vintage, 1996, p. 222.

35. Gaston Bachelard, Intuition of the Instant, Evanston, Illinois, Northwestern University Press, 2013, p. 27.

36. Gaston Bachelard, Intuition of the Instant, Evanston, Illinois, Northwestern University Press, 2013, p. 6.

37. Gaston Bachelard, Intuition of the Instant, Evanston, Illinois, Northwestern University Press, 2013, p. 7.

38. Christopher John Murray (ed.), Encyclopedia of Modern French Thought, Routledge, London/ New York, Routledge, 2004, p. 35.

39. Tom Tillemans, "Dharmakirti," in Edward N. Zalta(ed.), The Stanford Encyclopedia of Philosophy (Spring 2017 Edition). [Online] https://plato.stanford.edu/archives/spr2017/entries/ dharmakiirti/ [accessed 13 April 2021].

40. Martin Jay, "Magical nominalism: Photography and the re-enchantment of the world," Culture, Theory and Critique, vol. 50, no. 2-3, 2009, p. 181. 
41. Martin Jay, "Magical nominalism: Photography and the re-enchantment of the world," Culture, Theory and Critique, vol. 50, no. 2-3, 2009, p. 181.

42. Len Pisman, The Swings of Science. From Complexity to Simplicity and Back, Cham, Springer, 2018, p. 96.

43. Oli Sharpe, "All recordable human discourse is trapped in aleph-zero," presented at the 09/2018, PPIG 2018 - 29th Annual Conference, 2018. [Online] https://www.ppig.org/files/2018PPIG-29th-sharpe.pdf [accessed 13 April 2021].

\section{ABSTRACTS}

"Of Instagrammatology" starts with a trip to India I took with my wife in 2019 as the starting point for a meditation on the experience of time passing. I recount my attempt to finish reading Marcel Proust's In Search of Lost Time on the trip, having read the first two thirds over thirty years ago, while in India in my mid-twenties. This allows me also to reflect upon the extraordinary technical and cultural changes that have taken place in the interval between these two trips, especially in terms of communication. I suggest there is a connection between how I have found myself using technologies such as Instagram and Proust's own concern with the lost instant, and that both are manifestations of what Galen Strawson calls the "episodic self," and which is also found in some Buddhist philosophy. Finally I look at the idea, first found in Borges' story "The Library of Babel," and now instantiated online, that every moment of time, both in the past and in the future, is, in some sense, already describable in the infinity of Cantor's Aleph Zero

\section{INDEX}

Keywords: Marcel Proust, Galen Strawson, instant, Gaston Bachelard, Jorge Luis Borges, Georg Cantor, Aleph Zero, India, Dignana, Dharmakirti

\section{AUTHOR}

\section{CHARLIE GERE}

Charlie Gere is Professor of Media Theory and History in the Lancaster Institute for Contemporary Arts, Lancaster University. He is the author of Digital Culture ([2002] 2008), Art, Time and Technology (2006), Community without Community in Digital Culture (2012), Unnatural Theology. Religion, Art and Media after the Death of God (2019), and I Hate the Lake District (2020), as well as co-editor of White Heat Cold Technology (2009), Art Practice in a Digital Culture (2010), as well as many book chapters and journal papers. He has co-curated exhibitions both in Britain and abroad. 